\title{
MAJOR ISSUES OF WAGE POLICY IN AFRICA
}

\author{
by \\ Elliot J. Berg
}

CRED Reprints

(New Series)

No. 2

Center for Research on Economic Development

University of Michigan

Ann Arbor, Michigan 48104 



\section{MAJOR ISSUES OF WAGE POLICY IN AFRICA}

B Y

ELLIOT J. BERG

THE framing of an effective wages policy is nowhere easy, but is especially difficult, and especially important, in developing areas. The degree of government control over wage determination, whether direct or indirect, tends to be greater in these areas, so the impact of public policy decisions is sharper and more extensive. The consequences of error are greater, in both political and economic terms ; no element of economic policy touches more sensitive political nerves, none is so capable of shaking the fragile foundations of the state itself. In the poor countries, furthermore, there is less income to distribute, at the same time that social goals tend to be generously defined ; between social objectives and budget restraints or market imperatives the gap is distressingly large.

In this paper the main focus is on minimum wage policy, with some briefer consideration given to problems of wage structure and the implications for trade unionism and collective bargaining. The geographical focus of discussion is Tropical Africa, partly because this is the area I know best, partly to avoid the ascent to a level of generality which makes applicability to any specific area difficult. Even 'Tropical Africa' is an abstraction masking an enormous diversity of conditions, and exceptions can be found to most of the generalizations put forward below. There is, however, a sufficient homogeneity in environment and in stage of development to make Tropical Africa a meaningful unit of analysis.

Much of what follows is controversial. There is a need for controversy in this area, for there has been too little of it in the past. A decade ago the important Kenya Committee on African Wages (1953) put forward far-reaching recommendations on wage policy. But it had no economist among its members, nor did it consult one, on the extraordinary grounds that since economists differed amongst themselves anyway, and one could contradict another, it was better to do without their services altogether! This is one view of how to proceed in matters of wage policy - happily a minority view. The 


\section{Decision-Making Power in Wage Determination}

analysis below is based on another view - that plain talk and sharp dispute are preludes to sound policy.

Its purpose is twofold. First, to explore in some detail the economic implications of wage policy decisions, as a problem in itself. The wage problem is after all close to the heart of industrial relations, in developing countries perhaps more than others. It is for this reason that matters seemingly far from the union office or the negotiating table come under rather extensive discussion here, such as the relationship between wages, diet and productivity, and the economics of the migrant labour system.

The second purpose is of more immediate and direct relevance to the industrial relations issues which are the main concern of this Conference. This is to make clear the character of the economic environment within which industrial relations problems in Africa unfold. It is an uncommonly harsh environment, in which painful adjustments need to be made.

\section{MINIMUM WAGE POLICY}

Governments in Africa have long been major influences on wage levels, directly - through statutory minimum wages for unskilled labour and through the establishment of Wages Boards on regional or industrial bases - and indirectly, through their own policies with respect to government-employed labour. Of all government wage decisions, determination of the level of the minimum rate for unskilled labour has been both the most important and the most difficult. In Africa, unlike most advanced regions, minimum wage policy directly affects the majority of wage earners. It is an 'effective' rate in most cases, above prevailing rates. It determines the wage paid to that of 50 per cent or thereabouts of the wage-earning labour force which is unskilled and paid at the established minimums. It is also the key rate in the wage structure ; when minimum wages change, the entire wage structure tends to move with it.

\section{(a) Objectives}

In most parts of the world the objectives of minimum wage policy are mainly to impose on low paying firms and industries a wage level already achieved and generally far exceeded by most firms. Wage criteria such as prevailing wages and capacity to pay determine the level at which the minimums should be fixed.

In Africa the situation is different. Since government tends to set the wage pattern in its minimum wage policy, the traditional wage 


\section{Berg-Major Issues of Wage Policy in Africa}

criteria are less relevant. Minimum wage policy is used as a positive instrument of economic and social change. Its objectives are not simply to protect a minority of relatively low paid workers, but to raise the whole level of wages of unskilled workers, with overall social and economic objectives in sight.

Two objectives have been of overriding importance in most of the continent: the provision of an acceptable minimum standard of living for the lowest-paid wage earners, and the use of minimum wage policy as a means of prodding employers to more efficient utilization of labour. The two objectives are closely related. Definition of a minimum living standard immediately raises the question of 'for whom' : a wage earner who is a bachelor or has left his family in the village while he works temporarily for wages, or a man with a family to support. In practice, wages of unskilled workers in most of the continent are not adequate to support a family on a minimum standard. Minimum wages follow prevailing patterns in this respect ; they are based on theoretical needs of bachelors, but almost everywhere this is regarded as an unsatisfactory state of affairs, and is the main rationale for the other major objective - raising productivity through higher wage levels. Only if there is a stabilized, and hence more efficient, labour force will a family wage become possible.

Underlying these objectives is a more basic goal - to change the economic structure of the wage sector, in the direction of a more capital-intensive technology utilizing more settled, skilled, productive and highly paid workers. Implicit in this goal is the destruction or decline of the migrant labour system, without which such changes cannot be brought about. Minimum wage policy in much of Africa is explicitly or implicitly aimed at the migrancy system.

\section{(b) The Economic Setting}

Wage problems cannot be considered without some appreciation of the character of African economies. It is thus useful at the outset to set down some of the main features of these economies.

1. Importance of agriculture and subsistence production. Between 80 and 90 per cent of Africa's population lives in rural areas and lives mainly from agriculture. Agriculture accounts for between one-third and two-thirds of national output, except in Northern Rhodesia and South Africa. Manufacturing generates less than 10 per cent of national income everywhere except in Kenya, the Congo (before 1960), Southern Rhodesia and South Africa. Within the agricultural sector, subsistence activity predominates ; most Africans spend most of their productive time growing food for their own consumption. 


\section{Decision-Making Power in Wage Determination}

2. Open economies. African economies are 'open'; they export between 25 and 60 per cent of marketed production, and between 25 and 35 per cent of national expenditure consists of imports. In the commodities they export they tend, like most poor regions, to be specialized on one or two commodities - groundnuts in Senegal, Mali, Niger, Gambia ; cocoa and gold in Ghana ; cocoa and coffee in the Ivory Coast ; copper in Northern Rhodesia, etc.

3. Low population densities. Most African countries are thinly populated. There are a few areas where population pressures exist, and population growth everywhere appears to be high (about 2 per cent a year). But land remains relatively abundant in most areas.

4. Small wage sectors. In all African countries, wage and salary earners are a small proportion of the total population - less than 10 per cent in most of the continent. If the allocation of adult males alone is considered, the wage sector takes on a more substantial appearance, particularly in the Rhodesias; in Northern Rhodesia for example, more than half of the adult males of the country work for wages. This is an exceptionally high figure, however. As a general rule, wage earners are a small minority of the population.

5. Migrant labour. A large part of the paid labour force is composed of 'migrant' workers - villagers who are temporarily in paid employment. Some - notably in West Africa - work seasonally, for six or nine months during the dry season. Others work for one to three years, and occasionally longer. They are usually young men and unmarried. If married they leave their wives and children in the villages. They often come long distances. Many of them cross political boundaries ; half the Southern Rhodesian and Ivory Coast labour forces consists of 'foreign' migrants, and 10-20 per cent of the work force in South Africa, Ghana and Uganda. Because of lack of data and conceptual problems (the difficulty of defining a 'migrant') the proportion of migrants in the total paid labour force is not known with any precision. It is probably in the neighbourhood of half the paid work force in most countries.

6. Large public sector. Government is usually a large employer of labour, employing between 25 and 40 per cent of the recorded labour force in most countries. In several cases where government employment is relatively less important in Northern Rhodesia, Southern Rhodesia, Nyasaland and the Ivory Coast, it is less than 15 per cent ; the share of government in total wage payments is none the less substantial -26 per cent in Nyasaland and 30 per cent in the Ivory Coast, for example. 


\section{Berg-Major Issues of Wage Policy in Africa}

\section{(c) The Case for 'An Economy of High Wages'}

Recommendations for higher minimum wages in Africa have come from many different sources in Africa - politicians, trade unionists, members of wage boards and outside observers. ${ }^{I}$ Although many arguments are used to defend such recommendations, three are most common and most important. The first is social in nature - that on present wage earnings most Africans cannot live decently. The second is that with higher wages the physical condition of the work force will improve and individual efficiency will rise, offsetting the wage increase. The third is that with higher wage levels employers will adopt more capital-intensive techniques of production, the structure of the modern sector of the economy will change, labour migration as a system of labour utilization will disappear, and the payment of a 'family wage' will be possible.

That most African wage earners are poor, and many desperately poor, is not in question. Almost all Africans are poor. It is relative positions that are of importance in considering wage policy, and however low their income and welfare by some absolute yardstick, African wage earners are in general a relatively privileged group in African society. They enjoy more of the benefits of modernization and growth than any African social group. Their children have easier access to schools. ${ }^{2}$ They have available more and better medical care, and a larger share of the conveniences and amusements of modern life - from supermarkets to cinemas.

This position of relative privilege is suggested by data on income distribution between wage and non-wage sectors of African communities. Some sizeable difference in incomes between the two sectors is of course natural. Productivity is much higher in the wage sector, as are costs of living. But the differences none the less appear very large.

Precise measurement of these income differentials is difficult. The data for most countries are inadequate, and lack of occupational specialization and other problems in any case make such comparisons of uncertain meaning. But where data for comparisons are available they show average wage incomes to be much higher than average

I Cf. Kenya Colony, Report of the Committee on African Wages (Nairobi, 1954); Tanganyika, Report of the Territorial Minimum Wages Board (Dar-es-Salaam, 1962); ICFTU, Labour College, Kampala, Submission to Uganda Minimum Wages Board (Kampala, 1961) ; ICFTU, Report of the First African Regional Trade Union Conference, January 1957, p. 143 ; L. Katzen, 'The Case for Minimum Wage Legislation in South Africa', South African Fournal of Economics, XXIX, No. 3, September 1961, pp. 195-212.

2 School enrolment ratios in urban areas are often three or four times as high as in rural areas.

I.R.E.D. - $-\mathrm{H}$ 


\section{Decision-Making Power in Wage Determination}

incomes in the non-wage sector (including the money value of subsistence output). In the Belgian Congo in 1958, for example, income per capita was 3800 francs in the wage sector and 1400 francs in the non-wage sector, and in Senegal in the late 1950's it was estimated that wage income per capita was more than twice as high as incomes of traders and artisans, and more than three times higher than peaasnt and fishermen's income. Wage-earning families, representing a little over 10 per cent of the African population, earned one-third of African incomes.

Of greater significance than comparison of income levels at a moment of time is the direction and magnitude of changes over time in relative income movements of different African groups in the money economy. Wage earners in most African countries have substantially improved their position in recent years, relative to the other main African groups in the money economy. Also real incomes of wage earners have risen very appreciably in the past 15 years. In West African cities between the late 1940's and the early 1960's, real wages rose in the order of 30-50 per cent. In the Congo, between 1950 and 1958, real wages doubled and in Southern Rhodesia between 1949 and 1958 they rose by almost 70 per cent. Everywhere wage increases far outpaced improvements in income of farmers. On equity grounds, then, it is hard to see justification for widening these differences through minimum wage policies.

\section{WAGE INCREASES AND INDIVIDUAL EFFICIENCY}

The second major argument for a high wage policy is based on the presumption that higher wages will lead to greater output per worker through increased worker effort. The argument has a splendid simplicity. With higher incomes workers will be better fed, clothed and housed, and so able to work harder. Individual effort outlays will increase and productivity will rise, thus offsetting the increase in wages.

In fact, of course, there are in this formulation a long series of implicit assumptions and hypotheses: (1) that the wage earner's poor physical condition is due mainly to improper diet and living conditions in wage employment ; (2) that increases in wage income will be spent on more nutritious food and other items which directly affect the physical capacity to produce; (2) that better health will increase individual effort and effectiveness which will mean significantly greater output per worker. In considering the validity of these assumptions we will focus on nutrition, since it is this that 


\section{Berg-Major Issues of Wage Policy in Africa}

receives most attention in the literature and policy discussions on this matter.

\section{(1) The Relationship Between Worker, Diet and Health}

At the cost of some violation of medical reality the African's physical disabilities can be thought of as arising from three general sources. The first is the overall health environment - the plentiful presence of the diseases and parasites that prey on men in poor, hot countries : malaria, schistomosiasis, intestinal and enteric parasites of all shapes, amoebic and bacillary dysentery, sleeping sickness, leprosy, etc., as well as those diseases such as tuberculosis and venereal disease familiar in temperate countries. Medical examination of even apparently robust Africans often reveals a terrifying underworld of affliction. ${ }^{I}$

The second source of ill health is chronic malnutrition, the weakening of the individual that arises from bad nutrition over a long time, and particularly in early childhood and adolescence. The most dramatic and important manifestation is kwashiorkor - a protein deficiency disease which occurs mainly among children after weaning. The full long-term effects of kwashiorkor are imperfectly known, but it has been argued that it has fundamental and possibly ineradicable effects. ${ }^{2}$

The third source of African debility can be called 'simple malnutrition'. It involves current nutritional deficits - mild or temporary inadequacies in consumption of some nutritive elements.

While these distinctions are admittedly artificial, they do help bring out the complexity of the diet-health relationship, and underline the fact that bad current wage earner diets (and other inadequacies in physical conditions of life) are not the only or even the most significant source of ill health. They suggest the following observations :

(a) The energizing impact of better diet, if everything else remains the same, will be offset by the continued ravages of disease in the general public health environment. ${ }^{3}$

(b) To the extent that present physical weakness is due to organic disabilities arising from chronic malnutrition, the effects of better current food intake by adult wage earners will be slight,

I Cf. the summary of evidence in Commission for Technical Co-operation in Africa (CCTA), Inter-African Labour Institute, Human Factors of Productivity in Africa: A Preliminary Survey, ch. I.

2 C. H. Northcott, ed., African Labour Efficiency Survey, 1947 (HMSO, 1949), pp. $86 \mathrm{ff}$.

3 Cf. FAO, Nutrition and Working Efficiency, Freedom from Hunger Campaign, Basic Study No. 5 (Rome, 1962), p. 23. 


\section{Decision-Making Power in Wage Determination}

or very long-term. Chronic malnutrition yields stubbornly, or not at all, to better nutrition in adult life. ${ }^{\mathrm{I}}$

(c) The health impact of improved wage earner diet depends on the extent to which present wage earner diets approach adequate standards. Though little is known about the shape of the function that relates food intake to health, it is reasonable to suppose that it rises sharply from low levels and flattens quickly once needs are met. Since the evidence suggests that current wage earner diets are not grossly deficient, substantial effects in health improvement cannot be anticipated from better diet.

This raises the basic question until now left to one side : how badly fed are African wage earners? The answer must be tentative ; hard information is scarce, and there is great variation over time and between places.

There is none the less a generalized folklore on this question. The British writer, Jack Woddis, for example, cites with approval the statement that 'laboratory rats, fed on a typical African's diet, will eat their own offspring'. ${ }^{2}$ And he goes on to write about 'the semistarvation of African workers'. ${ }^{3}$ Similar though less extreme statements have come from more sober sources. ${ }^{4}$

The main trouble with these statements is that they rest on an exceedingly fragile factual base, and such evidence as is available does not support them. The general consensus among students of African nutrition, based on fragmentary evidence, seems to be that calorie intake is broadly sufficient, but that protein shortage is common, especially among children and pregnant and nursing women, and vitamin deficiency ( $\mathrm{A}$ and $\mathrm{C}$ especially) exists in some areas. Kwashiorkor is the most basic nutritional problem, and children, adolescents and pregnant and nursing women the most nutritionally underprivileged groups. ${ }^{5}$

As for wage earner diets in particular, the belief that they are

I C. H. Northcott, ed., op. cit. pp. 89-92. The authors of The African Factory Worker (Department of Economics, University of Natal) point out that chronic malnutrition takes a long time to disappear, but are more optimistic about the possibilities of dealing with it than is Northcott.

2 The New Scientist, August 20,1959, cited in Jack Woddis, Africa: Roots of Revolt (London, 1960), p. 165.

3 Ibid. p. 172. For more of the same, see Jose de Castro, The Geography of Hunger (London, 1952), p. 192.

4 Cf. U.K. report cited in CCTA, op. cit., ch. I.

5 Cf. FAO Africa Survey, Report on the Possibilities of African Rural Development . . . (Rome, 1962), pp. 24 ff.; ILO, African Labour Survey, 1958, p. 150; W. O. Jones, 'Food and Agricultural Economies of Tropical Africa', in Stanford Food Research Institute Studies, Vol. II, No. 1, February 1961, p. 5; FAO, Nutrition Meetings Report Series, No. 25, p. 21. 


\section{Berg-Major Issues of Wage Policy in Africa}

inadequate rests on three sorts of 'evidence'. The first is clinical testimony - medical examinations which reveal widespread 'symptoms of malnutrition'. ${ }^{\text {I }}$ The second is anecdotal - casual empiricism, consisting of reported instances where improvement in diet led to dramatic increases in output. ${ }^{2}$ The third is of an a priori or presumptive sort. It has been argued that wage incomes are so low relative to the cost of necessities that many African wage earners cannot conceivably feed (or clothe or house) themselves adequately. This is the thrust of the conclusions of 'Poverty Datum Line Studies', which have been made in a number of countries in Southern and East Africa. ${ }^{3}$

None of this evidence is persuasive. It presents a cheerless picture of the health and welfare of most urban African workers, but it does not demonstrate the existence of gross dietary inadequacy among Africans while they are in wage employment. The existence of 'signs of malnutrition' leaves much in the shadows : the severity of the malnutrition, for example, and whether it is of the chronic type, only remotely related to inadequacy of current food intake. ${ }^{4}$

The anecdotal evidence is even less indicative that current wage earner diets are insufficient for good health. Most of it is old ; examples are cited from the 1920's or 1930's. Often special work forces are involved (railroad construction crews, freshly recruited from the villages, for example). Often the evidence is highly indirect, showing a decrease in absenteeism after free mid-day meals are introduced. ${ }^{5}$

The presumptive evidence from Poverty Datum Line studies, finally, is least impressive of all. The PDL 'requirements' are not 'objective', but arbitrary. The true minimum diets, for example,

I The African Factory Worker, p. 176 ; African Labour Efficiency Survey, p. 88 ; Tanganyika, Report of the Territorial Minimum Wages Board (Dar-es-Salaam, 1962).

2 Cf. FAO, Nutrition and Working Efficiency, pp. 20 ff., and CCTA, op. cit., ch. I.

3 D. G. Bettison and P. J. Rigby, Patterns of Income and Expenditure, BlantyreLimbe, Nyasaland (Lusaka, Rhodes-Livingstone Institute, 1961) ; D. G. Bettison, Cash Wages and Occupational Structure, Blantyre-Limbe, Nyasaland (RhodesLivingstone Communication No. 9, Lusaka, 1958); Colony and Protectorate of Kenya, Report of the Committee on African Wages (Nairobi, 1954); Southern Rhodesia, Report of the Urban African Affairs Commission, 1958 (Salisbury, 1958); D. G. Bettison, 'The Poverty Datum Line in Central Africa', Rhodes-Livingstone Fournal, Human Problems in British Central Africa, No. 27, 1960 ; Tanganyika, Report of the Territorial Minimum Wages Board (Dar-es-Salaam, 1962).

4 In the African Labour Efficiency Survey, the basic factor was said to be long-term malnutrition; current diets were adequate. The Dunlop rubber factory study (The African Factory Worker) also emphasized chronic malnutrition, but the dietary survey found inadequacies in current intake. Only a few of the families were, however, far from required consumption norms. (African Labour Efficiency Survey, pp. 87, 107; The African Factory Worker, pp. 6, 182-184.

5 Cf. FAO, Nutrition and Working Efficiency, pp. 21-22; CCTA, op. cit., ch. I. 


\section{Decision-Making Power in Wage Determination}

are much below those in the PDL studies, both in nutritive content and in cost. ${ }^{1}$

The 'evidence' for bad wage earner diet is hardly overwhelming. It is weakened further by the most relevant data of all - resort to the facts as they appear in actual urban household expenditure surveys of recent years. These have a large margin of error, but are the most reliable data available. The results of these studies show that except for married households in Salisbury, Southern Rhodesia, and for one or two nutrients in most cities, apparent consumption is roughly in line with minimum nutritional needs. ${ }^{2}$

\section{(2) Wage Increases and Health-improving Expenditure}

Higher wages will lead to improved health only to the extent that increments of income are spent on health-improving goods. Such goods can, in the African context, be very broadly defined. They embrace purchases of shoes, screening for houses, bicycles, sleeping mats, warm clothing; all might contribute to protection against illness or conservation of energy. But such expenditure ceases, at a very low level, to add to physical protection and physiological wellbeing. Most African workers already have some footwear, and some protection against the chill of night. Also not many have to walk long distances to work. The health impact of expenditures along these lines is likely therefore to be small in most areas. It is in the nutrition area that the most important effects might be looked for.

Household budget surveys do in fact suggest that some improvement in nutrition is likely to follow higher incomes : consumption of meat, fish and milk, major sources of good protein, seems to be responsive to increases in income. ${ }^{3}$ But the data are not altogether reassuring. Where nutritive intake is available by income groups, it suggests that qualitative improvements in food consumption respond rather sluggishly to increased incomes, particularly at lower

I Cf. B. Thomson and G. Kay, 'A Note on the Poverty Datum Line in Northern Rhodesia', in Rhodes-Livingstone Institute Fournal, Human Problems in British Central Africa, December 1961, pp. 40-49. In Blantyre, Nyasaland, the cost of a nutritionally satisfactory diet was found to be half the cost given in the PDL study for that city : 50 cents per adult male per week. See D. G. Bettison and P. J. Rigby, Patterns of Income and Expenditure, Blantyre-Limbe, Nyasaland, RhodesLivingstone Communication, No. 20, Lusaka, 1961, p. 110.

2 See Northern Rhodesia, First Report on Urban Budget Surveys, I960 (mimeographed), Tables 8 and 9 ; Southern Rhodesia, Second Report on Urban African Budget Survey in Salisbury, 1957/58, Tables IV and VI ; Bettison and Rigby, op. cit., Table IX ; T. Poelman, 'Ghana's Urban Food Economy', Food Research Institute Studies, May 1961.

3 Thus an analysis of budget data in seven African cities suggests that a 10 per cent rise in wage income would probably lead to a 6-9 per cent rise in spending on meat. See H. Kaneda and B. F. Johnston, 'Urban Food Expenditure Patterns in Tropical Africa', Food Research Institute Studies, II, November 2, 1961, pp. 260265. 


\section{Berg-Major Issues of Wage Policy in Africa}

levels of income. Where significant deficiencies exist, they tend to persist over the whole income range. ${ }^{\mathrm{I}}$

A number of factors combine to reduce the impact of income increases on the quality of diets :

(a) Many of the lowest paid workers are migrants, villagers in temporary employment who have a high average and very high marginal propensity to save. For these workers, the lowest income group in most wage labour forces in Africa, higher wages will mean more remittances to their home countries, or purchases of consumer durables to take back with them, rather than better eating while in wage employment. ${ }^{2}$

(b) Income level and size of household are commonly associated in African cities. This is probably due to the operation of the extended family system ; increments of income are followed by increments of kinsmen to share it.

(c) Not all foods which have high income elasticities are nutritionally better. Higher incomes may (as in Ghana) allow a shift from cassava to yams and plantain, which are only slightly more nutritious, but are more desired for convenience and taste. Even more common is the shift to bread consumption as incomes rise; this is fine when cassava is the abandoned staple, but when bread is substituted for rice, the improvement is not nutritionally noteworthy. There may, finally, be an inverse relationship between income elasticity and nutritive value; the best example is the tendency noted in one city (Blantyre) for fresh fish to replace dried fish as incomes rise. The latter is much richer nutritionally.

(d) Finally, and most important, much nutritional trouble arises not from lack of income but from lack of knowledge and the hold of custom. This is particularly the case with respect to the feeding of children and women. ${ }^{3}$ Chronic malnutrition is traceable at least in part to this state of affairs, which is not likely to be much changed by income rises unless accompanied by new awareness of the nutritional needs of children and women.

I Cf. Second Report on Urban African Budget Survey in Salisbury, 1957-8, Tables, pp. 13, 14 ; First Report on Urban African Budget Survey held in Northern Rhodesia, May to Áugust 1960, Table, p. 8.

2 See East Africa Statistical Department, Uganda Unit, The Patterns of Income, Expenditure and Consumption of African Unskilled Workers in Kampala, February 1957, p. 8. Labourers originating in the Congo and Ruanda Urundi, and in the distant (poor) regions of Uganda, saved in 1957 at four times the rate of Ganda labourers.

3 Cf. FAO Africa Survey, op. cit. p. 27. 


\section{(3) The Relationship between Health and Productivity}

Even if an income rise should, through better nutrition and other health-improving consumption, lead to better health, the effects on productivity might not be significant. Except in cases of gross physical debility, or caloric deficiency, and in the absence of psychological changes and new incentives, there is no self-evident reason why an African should work harder simply because he feels better and can work harder. Individual intensity of work, in any case, is only one factor affecting output per man. The level of skill and training, degree of capital intensity, quantity and quality of supervision, effectiveness of work organization and general management performance - these factors outweigh individual intensity of effort in explaining the level of output per worker.

This analysis throws considerable doubt on the argument that increased incomes will lead to better health and to greater individual efficiency. It provides a most uncertain base for defence of a high minimum wage policy. Even if diet and health is in fact a major determinant of poor work performance there are more efficient ways to deal with it than minimum wage policy - subsidized employerprovided meals, for example. If chronic malnutrition is a more basic health problem, then nutrition education, school feeding, etc., are better designed to deal with it. If endemic disease is most crucial, public health measures are called for. If all these things could be done, there would be no problem. But it is not a question of higher wages and health measures. To an unpleasant degree, it is higher wages or these and other measures.

\section{STRUCTURAL CHANGE AND ELIMINATION OF THE MIGRANT LABOUR SYSTEM}

The most common justification for a higher minimum wage rate is that it will bring about a technology resting on more capital-intensive techniques, and that this kind of economic structure, even though it implies lower employment, is more conducive to growth than the present structure. A high wage policy will encourage the development of a stable and more efficient labour force, diminishing the reliance on migrants. All this can be achieved without undue concern over unemployment, precisely because most workers are uncommitted to wage employment and those who do not find wage employment will return to their villages where land remains relatively plentiful. ${ }^{1}$

I The best expressions of these arguments are to be found in Tanganyika, Report of the Territorial Minimum Wages Board (Dar-es-Salaam, 1962); and Kenya Colony, Report of the Committee on African Wages (Nairobi, 1954). 


\section{Berg-Major Issues of Wage Policy in Africa}

The migrancy phenomenon, it is generally argued, is largely responsible for the low level of African productivity because it causes high labour turnover and hinders the acquisition of skills. It is also held to account for the low level of wages, which are fixed at a 'bachelor' standard, sufficient to attract migrants who leave their families in the villages, but not high enough to support a man with his family. It is also said that migrancy retards agricultural development, since the village economy becomes the instrument of women, children and old people, and since men who can earn enough to satisfy minimum needs by temporary employment outside have little incentive to improve their own agriculture. ${ }^{I}$

For all these reasons, continued reliance on migrant labour is believed to be economically inefficient. A higher wage level will lead to its demise. If wages are high enough to support families, men will be prepared to become permanent wage earners, and employers will have to adopt methods of production in accord with higher wage levels, which means fewer, better-trained and higherpaid workers.

This line of argument is open to serious question on several counts. Migrancy is hardly the cause of the evils associated with it; it is rather a symptom of a specific set of circumstances in the economic environment, and will diminish as these change. Nor is migrancy necessarily harmful to development; it allows a higher level of income than any alternative arrangement, under present conditions. Minimum wage policy alone, finally, is not sufficient to change it ; more extensive and very expensive additional changes are required.

The migrant labour system arose and persists in Africa for certain basic reasons. Historically, it developed because places where wage labour was needed were often far from population concentrations, and African villagers were men with land, members of a tightly knit social organization which they were not disposed to abandon. It persists in part because it is the most efficient way to meet money needs in the village ; it allows the maximization of family incomes, since the migrants' families continue to cultivate in the villages while migrants are away. It persists as well because some employers (in agriculture) do not find it inconvenient and others (as in construction) have adjusted to it by introduction, for example, of piece-work methods which reduce the impact of inefficiency on costs. Also, a labour stabilization policy involves large social overhead investments in housing and other facilities, which neither employers nor governments have been anxious to undertake.

I Cf. 'Interracial Wage Structure in Certain Parts of Africa', International Labour Review, Vol. 78, No. 1, July 1958, pp. 20-55. 


\section{Decision-Making Power in Wage Determination}

To analyse the effects of migrant labour let us think of an economy with two sectors. The first consists of subsistence-oriented villages. A few cash crops may be grown, but most of the villagers' money income is earned by migration of men outside the villages. For want of a better name, and with apologies for its gracelessness, we will call this sector 'Villagia'. The second sector is where the migrants work. Here there are two main types of economic activity, large-scale enterprises, and household enterprises, mainly agricultural, producing for the market and using hired labour. This sector we will call 'Modernia'. The labour force in Modernia consists of two groups migrants from Villagia and residents of Modernia.

What is the effect of labour migration on each of the sectors ? The people of Villagia, first of all, enjoy a higher level of income with migration than without it. Most villagers migrate because they can earn higher incomes in Modernia than in Villagia, or can earn the same incomes with less effort. The net gain to Villagia as a whole is greatest when migration is seasonal, as much of it is in West Africa. In this case village output suffers relatively little. Most men leave after the harvest and return in time for new planting. There is some decline in village output, but it is minor. Seasonal migration simply absorbs underemployed labour in Villagia.

When migration is longer-term - one to three years - the situation is more complex, but the results are the same - a higher level of income in Villagia. Villagia's output declines, but much less than proportionately to the temporary decline in its population through migration. Many men clear land which their families can cultivate in their absence, the migrants' families work harder, and other villagers help through co-operative work arrangements, and other forms of mutual aid common in African villages. Village capital formation suffers neglect, and cash crop output of Villagia declines (since cash cropping is usually 'men's work', abandoned for wage earning in Modernia). But the declines in village output are more than outweighed by migrant earnings. There is a growing body of evidence that the villages tend to maintain themselves well even in the absence of 50 per cent or more of their young men. ${ }^{\mathrm{I}}$

What about the effect of immigration on Modernia ? Its benefits are clear. The inflow of migrants increases the supply of labour available to its enterprises, permits a higher level of output, employment and income, a greater volume of investment and a general

I Cf. W. Watson, Tribal Cohesion in a Money Economy (Manchester, 1958); J. Van Velsen, 'Labour Migration as a Positive Factor in the Continuity of Tonga Tribe Society', in Economic Development and Cultural Change, Vol. 8, April 1960. See also, for general discussion of the economic aspects of migration, W. Elkan, Migrants and Proletarians (London, 1960). 


\section{Berg-Major Issues of Wage Policy in Africa}

widening of the scope of the money economy. Its household agricultural sector in particular is very dependent on the presence of migrants from Villagia. Not all groups in Modernia, however, are equally benefited. With immigration the general level of wages of unskilled labour is lower in the short run, as is the aggregate wage income of workers of local origin. But the gains in public and private revenues in Modernia due to higher output and accompanying structural change not only make available to local populations in Modernia a better network of public and private services, but increase the demand for local labour in the longer run.

Viewed from this perspective, migration is seen to benefit both the labour-exporting and labour-importing areas. It is possible to argue, however, that this is true only under static conditions, that while migrancy does indeed represent an optimum allocation of labour in the short run, it results in a low-level equilibrium trap for both Villagia and Modernia. In Villagia fundamental agricultural transformation is rendered impossible by the absence of males, and their unwillingness to turn attention to village agricultural modernization when they can meet their limited income needs by migrating to Modernia. ${ }^{I}$ In Modernia the economy becomes wedded to a highly labour-intensive, low productivity, low-wage technology. Only an aggressive minimum wage policy in Modernia can move both Villagia and Modernia out of their ruts.

In so far as Villagia is concerned, this argument seems to assume that agricultural revolution can be brought about without tremendous ancillary changes. If, somehow, men would only dedicate themselves to transforming subsistence agriculture the problem would be solved. But the development of agriculture in the relatively poorly endowed areas from which most of the migrants originate depends on markets and an enormous auxiliary investment - from roads to research. Both are scarce in Villagia, however. Modernia provides them. It is hard to see how reduction or curtailment of migration can improve Villagia's position. There are certain circumstances under which Villagia might be better off without, or with less migration, but these are unlikely to be general.

With respect to the modern sector of the economy, the record of the past two decades in most of Africa indicates little technological stagnation. Except in plantation agriculture, which is necessarily unskilled labour intensive, capital-intensive techniques have been widely introduced, and reliance on migrants appears to have slowly diminished. In manufacturing, and in semi-skilled jobs generally,

I Cf. P. H. Gulliver, Labour Migration in a Rural Economy, East African Studies, No. 6, Kampala, 1955, p. 35, for an expression of something like this argument. 


\section{Decision-Making Power in Wage Determination}

training costs become significant and it is in employers' interest to develop a stable work force. It is no surprise that stabilization of the work force has gone furthest in South Africa, despite its apartheid policies officially designed to prevent it.

A high wage policy, in any event, will not by itself bring stabilization of the work force. It may increase the desire of employers to have stabilized workers, but it will not necessarily increase the desire of villagers to be stabilized. For even at higher wages the villager still finds his family income is maximized when he migrates temporarily, leaving his family behind. This will change when permanent commitment to wage earning promises special advantages - such as the chance to obtain skilled employment and much higher income. It will also require decent housing, and possibly some kind of social security now provided in the village. The abolition of migrancy, in other words, implies massive public investments in social overheads.

There remains to consider one final facet of the migrant labour system - the fact that much migration takes place across national boundaries. The flow of migrants from across frontiers exercises a depressing effect on wage rates of local wage earners, and this poses a genuine dilemma. If immigration is restricted, the economic growth of the labour-importing country would be retarded; the transformation of the peasant sector would in many countries be particularly obstructed. On the other hand, if as one country's economy expanded it drew to itself labour from surrounding countries, real wage rates would rise only slowly.

This suggests the existence of a basic conflict of interest, in the short run at least, between wage earners of local origin and foreign migrants. This in turn implies that by combining higher minimum wages with restrictions on foriegn migrants some of the unemployment and other negative effects of a high wage policy can be exported to the countries where migrants originate. Broad issues of equity and inter-African relationships are involved here, with many ramifications.

\section{THE IMPERATIVES OF WAGES RESTRAINT}

We have tried to show that the main arguments in defence of a high wage policy are unconvincing. Considerations of equity do not provide persuasive reasons for improving wage earner incomes, given their position relative to other African groups. The goal of inducing structural change and elimination of migrancy is of dubious merit, and wage policy is in any case an expensive and uncertain instrument 


\section{Berg-Major Issues of Wage Policy in Africa}

to attain it. The expectation that higher wage incomes will result in higher individual efficiency through better health is questionable, and here, too, minimum wage policy is not the most efficient means to attain the stated objective.

The need for caution in wage policy which is implicit in the above analysis is magnified by consideration of the economic consequences of higher minimum wages. In at least four important respects a higher minimum wage has negative effects on economic development and change : (1) it reduces government services and capital formation ; (2) it reduces employment or slows its increase ; (3) it increases strains on the balance of payments ; (4) it restricts the expansion of peasant agriculture by redistribution of income from peasants to wage earners.

To simplify the analysis, the effects of changes in the minimum wage on the rest of the wage structure, and the productivity effects of the increase, are ignored in the following discussion.

1. Government activity. The most immediate, obvious and painful effects of a higher minimum wage are felt in the public treasury. The high proportion of the labour force employed by government is reflected in the public sector's substantial share of total wage payments. Governments pay between 25 and 60 per cent of the total African wage bill except in the Rhodesias. With a higher minimum wage government services will contract, other things unchanged, the impact varying according to unskilled labour intensity of the sector of activity; general administration, for example, will tend to be least affected while public works departments will be hardest hit. Government capital expenditures will also be adversely affected - again in the areas using most lower-graded labour - notably road and general construction. ${ }^{\text {I }}$

2. Employment. The volume of employment is affected in four ways. First, since unskilled labour is more expensive, employers seek to economize in its use. They tighten up on existing methods of work organization. These are the well-known 'shock effects' familiar in the general literature on wages. Secondly, they substitute machines for men, the change in relative prices making this worth while in cases where it was not before. ${ }^{2}$ Thirdly, some firms will find it impossible to meet the higher rates and will go out of business. And fourthly, some potential enterprises, particularly in agriculture, will never get started.

I Cf. Federation of Nigeria, Report of the Fact Finding Committee on the Minimum Wage Question (Lagos, 1955).

2 Cf. the account of responses to wage increases by the Northern Rhodesian copper industry, in Robert E. Baldwin, 'Wage Policy in a Dual Economy - the Case of Northern Rhodesia', in Race, IV, No. 1, November 1962, pp. 81-82. 


\section{Decision-Making Power in Wage Determination}

The record of the past fifteen years is suggestive in this respect. Under the impact of rising wage rates, periodic scarcities of labour, the development of new industry which adopted modern techniques and the high profits of existing enterprise, which encouraged renovation of plants along more capital-intensive lines, employment has in most African countries increased slowly. In almost all cases, employment has grown much less quickly than either wage rates or output.

3. Prices and the balance of payments. A higher wage level increases pressure on the balance of payments by increasing the demand for imports. African wage earners have high average and probably very high marginal propensities to import. In recent years between 20 and 30 per cent of African urban household expenditure has been devoted to imports. Even a higher percentage of any increment of wage income is likely to be spent on imports ; many of the non-food goods consumed at higher income levels are imported, and higher incomes induce shifts in food expenditure patterns favouring imports - bread for rice and cassava, for example. These income effects will be reinforced by price effects ; to the extent that the wage increase raises local costs it makes imports more attractive than locally produced goods.

All of this assumes that imports are not shut off because of balance of payments trouble. For most of Africa during the 1950's this was not an unrealistic assumption. It is one of the main reasons why wage changes had relatively little impact on consumer price levels ; large portions of added wage income tended to be siphoned off by increased imports. Since African purchases are a small portion of total sales of these imports (their supply to African countries is perfectly or highly elastic) their price was not much affected by a raise in African demand, except perhaps in the short-run period necessary to restock dealers' depleted shelves. This explains why there have been few wage-price spirals in the past in Africa. In practice the sequence has been reversed; much wage pressure has been aimed at maintaining a real income position in the face of rising prices originating from outside the wage sector.

The easy balance of payments situation of the 1950's no longer prevails in most of the continent ; import restrictions are increasingly common. Under these circumstances increased spending by wage earners is deflected to locally produced goods, which tend to be less elastic in supply than are imports. Thus the twin consequences of increased wage income are either further balance of payments pressure or upward pressure on consumer prices, or some combination of the two. 


\section{Berg-Major Issues of Wage Policy in Africa}

In addition to demand-induced price rises, there will be some costinduced rises, from two main sources. Since governments tend to meet higher wage costs (at a time when demand for services and public investment is intense) by higher taxes, there will be some taxinduced price rise on locally consumed goods and services. Secondly, producers for the local market will have higher costs, directly because of the higher wage rates, indirectly as taxes and prices of other inputs rise. Generalization about the likely magnitude of these rises is difficult ; the impact will tend to be most important in construction, where African labour costs are a relatively high proportion of total costs, and in manufacturing which is protected against imports by quantitative restrictions.

Higher wages will tend also to affect the balance of payments through declines in export earnings, if the export industries find their competitive position and ability to survive threatened by higher wage costs. An important segment of the continent's export industry is in fact vulnerable. Much of Africa's gold-mining industry, for example, is unhealthy because of the low-grade ores in many mines ; in Ghana most of the gold-mines were first subsidized, then nationalized, as they found themselves faced with inability to pay national minimum wages. The Tanganyika Minimum Wages Board also recommended subsidies to the gold-mines in that country to allow them to pay the recommended minimum. ${ }^{\mathrm{I}}$

Much plantation industry is in a similar situation. They are generally unskilled labour-intensive, low-productivity and low-wage enterprises. Their technological alternatives are not numerous, and in many cases they lack access to credit or capital markets. They tend to use piece-work systems of payment that allow workers easy access to leisure if they want it ; this makes it easier for them to recruit a labour supply, but renders application of minimum wages difficult. They produce crops (coffee, tea, rubber, sisal, bananas, palm products and others) for which there are low-cost competitors in other parts of the world. All of this means that the plantations are in general highly vulnerable. Minimum wage pressure can push many of them to the wall, and slow the expansion of most.

4. Income redistribution and agricultural expansion. Every increase in minimum wages leads to a redistribution of income in favour of the affected wage earners. Some redistribution may occur within the wage-earning sector from those whose real wages are reduced as a result of wage-induced tax and price rises. There is also some possibility for the cost of the wage increase to be shifted to foreigners - consumers of Africa's exports and investors in African firms.

I Tanganyika, Report . . ., op. cit. pp. 30-31. 


\section{Decision-Making Power in Wage Determination}

Much, if not most, of the burden, however, will fall on Africans outside the wage sector - mainly the rural population. This occurs most directly through government taxing and spending. African governments rely mainly on indirect taxes, and especially import and export duties, for public revenues. Although luxury goods tend to be taxed at high rates, and personal income taxes are mildly progressive, the tax burden under present arrangements falls heavily on the majority of the African population in the agricultural sector. The wage-induced increase in government's wage bill thus involves a redistribution of income from peasant to wage earner. The degree of redistribution is greatest in those economies based mainly on peasant production of export crops, for here African wage earnings account for only a small portion (less than a quarter) of total African money expenditure. In these economies, non-wage-earning Africans do most of the spending, and pay most of the taxes.

Redistribution of income from peasant to wage earner occurs in other ways. Farmers pay higher prices for the things they buy and enjoy fewer government services, or if government attempts to maintain its expenditure, they will pay higher taxes. Peasant producers may also receive lower prices for their export crops, partly because handling costs of export firms or marketing boards have risen, but mainly to find new sources of government revenue. The mainly subsistence-oriented villages will suffer a general decline in real income because reduction in wage employment following the wage increase (or the slower expansion of employment opportunities in the wage sector) will force more men to remain in the villages, and incomes per capita there will fall.

The equity implications of these income transfers are obvious. Here only their incentive effects will be noted. Reductions in the real incomes of peasant farmers, especially those in or on the margin of entry into cash crop agriculture, have negative incentive effects. They diminish the willingness of peasants to undertake the changes in ways of life, the risks, the uncertainties, the harder work and in some cases the cash outlay, required to make a fuller commitment to the market economy. Since the transfer of peasant energies and land from subsistence production and other activities to production for the market is the heart of the process of agricultural transformation, these indirect and seemingly remote consequences of wage policy are of great potential significance.

The general conclusions emerging from this analysis of minimum wage policy issues are evident enough - that caution and restraint are urgently demanded in the wages area. While the goal of a better standard of living for wage earners cannot but win wide approval, 


\section{Berg-Major Issues of Wage Policy in Africa}

the costs of a high wage policy are heavy and are not balanced by potential economic benefits. The widespread conception of minimum wage policy as a device to end the migrant labour system is particularly questionable; not only is the instrument expensive and uncertain, the goal itself is of dubious economic merit.

Most of the above arguments rest on objective economic conditions in countries in early stages of development. They flow from the imperatives of African economic development and the African economic environment, and are only superficially dependent on property relationships or ownership arrangements. They would in general terms apply, for example, to countries with African features in which all means of production were nationalized. In some ways they would apply even more to such countries than to the mixed economies of contemporary Africa. With respect to capital accumulation, for example, the minimum wage problem would present more acutely the same brutal dilemma faced by African governments today : the higher the level of minimum wages the fewer the roads, schools, hospitals and factories that the state can build and maintain. A socialist government, too, would have to frame wage policy with one eye on the agricultural sector, another on the balance of payments, and in the back of it all a concern for balancing equity in the sharing of burdens and benefits with the need to provide incentives for the expansion of output and productivity.

This does not mean that the African unskilled wage earner is for ever tied to a wage level too low to permit his family to subsist on wages alone, or that migration will remain a permanent feature of the African scene. Migrancy will come to an end in the non-agricultural sector, as is already happening, when conditions in village and town make it advisable for employers and advantageous for workers. Above all, as the villages come more fully into the money economy, and incomes rise there, wage earners will draw large benefits, for it is the level of village incomes which determines the supply of labour in paid employment, and this exercises a major influence on the level of wages.

\section{WAGE STRUCTURE}

We have so far been concerned only with the level of minimum wages. But the problem of wage levels cannot be considered apart from that of structure. One aspect of wage structure is of particular importance, the question of wage differentials for skill or education, and this question alone, for reasons of space, will receive attention here. 


\section{Decision-Making Power in Wage Determination}

There is in all of Africa an enormously wide spread between the wages of workers with little or no skill and those on the upper rungs of the skill ladder, in particular those in occupations ordinarily requiring secondary or higher education. Although there are differences between African countries, everywhere the gap between wages of unskilled labour and university graduate remuneration is far greater than is found in advanced industrial countries. In the U.S., for example, the ratio between the typical starting rate for a new university graduate and the national minimum wage is in few cases much more than $2: 1$, and since the actual wage of most unskilled workers is well above the statutory minimum, the true ratio is considerably lower. In African countries this ratio ranges from $6: 1$ to $11: 1$, with $7: 1$ the most common.

Differences in base pay are only part of the story. In African civil services in particular, but in private employment too, universitytrained employees enjoy an array of fringe benefits not shared by less educated and less skilled workers and indeed rarely found in such variety and magnitude in industrial countries : free housing, or housing at rents far below market prices, car allowances and loans at low interest for automobile purchase, extremely general vacation and leave allowance, free medical care, good pension schemes.

Differences in remuneration of this magnitude are hardly admissible from the point of view of equity, particularly in societies with ideological leanings of a socialist or other equalitarian cast. Their existence conditions all discussions of wage policy; it is difficult to counsel wage restraint on unskilled workers, many of whom are not far from the edge of a minimum subsistence income, when some wage earners have incomes permitting a level of living of high comfort. The same is true where political representatives - chiefs of state, cabinet ministers and their aides - live in what is regarded as undue opulence.

The problem is clear, but what to do about it is not. The remedy depends on how the causes for these differentials are diagnosed. It is possible to argue that they are 'artificially' large, symptoms of a 'colonial' wage structure: derived from historical circumstances of colonial rule. To recruit expatriates it was necessary to pay the prevailing wage in the country of origin, plus some (usually substantial) premium for the inconveniences of overseas service ; the fringe benefits were offered for similar reasons. As Africans took over 'senior' jobs formerly held by expatriates, the high base rates as well as most of the fringes tended to become absorbed into the wage structure. To not pay the same rates for the same jobs was politically unacceptable in the colonial environment. 


\section{Berg-Major Issues of Wage Policy in Africa}

There is doubtless something in this argument, particularly in so far as non-wage benefits are concerned. But the colonial heritage is not the major element accounting for the differentials. Market pressures, pressures of supply and demand, are more important. Trained, educated people are very scarce in these economies, and the demand for their services is great, while there are many claimants for unskilled work relative to the availability of unskilled jobs. It is true that the supply of educated Africans has been growing, and will grow faster as educational expansion yields its fruit. But the demand for their services has increased at a faster rate in the post-independence period, and this disparity will continue for some time in the future in most African countries. Market pressures are thus tending to widen the existing wage differentials even further.

These pressures, on the demand side, are in part external. As the market for educated people becomes increasingly international, Africans in certain key occupations - doctors, engineers, scientists - can find employment in advanced countries, usually but not only in the ex-metropolitan country; there are reported to be African engineers at work in Germany and the Scandinavian countries, for example. The United Nations and related agencies, and interAfrican organizations, set up a heavy demand for administrators, lawyers, economists. University lecturers have an ever-widening geographical market.

Even more important in many countries is internal competition between private employers and the civil service. Almost everywhere the private sector is offering salaries well above what is available to university-trained people in the civil service.

The dilemmas are obvious and acute. Ideological preferences are strongly in favour of a compressed salary structure everywhere in Africa. Supply and demand conditions, however, favour a large spread. The acceptability of wage restraint depends in great measure on a feeling of shared sacrifice to which a narrowing of differentials would make a major contribution. But demands for trained and educated people are increasing faster than their supply, which tends to make differentials even wider.

African governments have so far tried to contain the market pressures, and impose restraint. Civil service salaries at the upper levels have not changed, or changed very little in the past five years ; in some countries they have been reduced. ${ }^{I}$ The fringes and allowances have been under broad attack. Automobile privileges and

I In 1961 the Adu Commission in Tanganyika reduced starting rates for university graduates from $£ 798$ a year to $£ 702$. (Report of the Tanganyika Salaries Commission, 1961, Vol. I.) 


\section{Decision-Making Power in Wage Determination}

allowances have been reduced or eliminated in most countries and vacations have been shortened. The right to take occasional leave in Europe has been eliminated everywhere. Housing subsidies have been reduced and the intention is to eliminate them; usually those now housed retain their rights, but in at least one country (the Ivory Coast) all subsidized housing was eliminated at one stroke in 1962, which was estimated to be equivalent to a 30 per cent wage cut.

Aside from wider resort to progressive income taxes, it is hard to see feasible alternatives to this policy of maintaining money wages in the upper levels of the civil service, while cutting back on fringes. Rising price levels will give opportunity to reduce differentials in real terms, as will reductions in the fringe benefits, with the least difficulty. There are limits to such a policy. One is the strength of the international market in educated people, but this will be partly offset by the unwillingness of many to leave their country, and by the prospects of rapid promotion which still exist in many African countries. The continuing presence of numerous expatriates is another restraint. Their salaries and benefits are determined by other considerations, and as the gap between expatriate and local African salaries for similar jobs grows, resentment is inevitable. There is also likely to be one consequence of more basic long-term significance ; the civil service will tend to lose many of its most able people to the private sector. This is the heaviest price of all, and could be especially damaging in those African states where government is given the major role in economic development. An effective policy of wage restraint, however, demands it. This is another instance where the ramifications of wage policy reach into the heart of general economic policy and development strategy. 

